\title{
MENINGKATKAN HASIL BELAJAR MERODA SENAM LANTAI MELALUI PENGGUNAAN ALAT BANTU PEMBELAJARAN
}

\author{
Sabdoadi Dany Saputro ${ }^{(1)}$, Djoko Nugroho ${ }^{(2)}$ \\ ${ }^{(1)}$ Universitas Sebelas Maret Surakarta \\ ${ }^{(2)}$ Universitas Sebelas Maret Surakarta
}

\begin{abstract}
This study aims to improve the learning outcomes of students of junior high school in the academic year 2017/2018 through the use of learning aids.

This research is a classroom action research. This research was conducted in two cycles, with each cycle consisting of planning, action, observation, and reflection. The research subjects were students of of junior high school amount 32 students. Sources of data in this study come from teachers and students. Data collection techniques are by observation and evaluation of learning outcomes. Data analysis used descriptive techniques based on qualitative analysis with percentages.

The results of the analysis of research data can be presented as follows starting from pre-action to cycle I and from cycle I to cycle II. In pre-action, students have not shown good learning outcomes, excellent categories with a percentage of $0 \%$, good categories with a percentage of $3.125 \%$ or 1 student from 32 students, enough categories with a percentage of $53.125 \%$ or 17 students from 32 students, less categories with percentages $37.5 \%$ or 12 students from 32 students, then the category is very low with a percentage of $6.25 \%$ or 2 students from 32 students. In the first cycle the category is very good with a percentage of $0 \%$, a good category with a percentage of $3.125 \%$ or 1 student from 32 students, enough categories with a percentage of $68.75 \%$ or 22 students from 32 students, a category with a percentage of $28.125 \%$ or 9 students from 32 students, and very few categories with a percentage of $0 \%$, from the data there can be a number of 23 students have reached the criteria of completion while 9 students have not yet completed. In cycle II it reached a very good percentage of $0 \%$, a good category of $18.75 \%$ or 6 students of 32 students, quite a category of $65.625 \%$ or 21 students of 32 students, a category of $15.625 \%$ or 5 students of 32 students, and less than 0\%. So that from the data it can be seen that 27 students reach the criteria of completion while 5 students have not finished with the number of students 32 students.

The conclusion of this study is that the use of learning aids can improve the learning outcomes of floor gymnastics of junior high school.
\end{abstract}

Keywords: learning outcomes, cartoons, learning aids 


\section{PENDAHULUAN}

Pendidikan menjadi bagian penting dari kehidupan manusia, dengan adanya pendidikan maka manusia mampu memperoleh sesuatu yang lebih baik dari sebelumnya. Melalui pendidikan manusia mendapatkan pengetahuan dan pengalaman yang baru yang berguna untuk hidupnya. Pengetahuan dan pengalaman tersebut didapatkan melalui pendidikan baik itu pendidikan lewat lembaga formal maupun nonformal. Yang dimaksud dengan lembaga formal pendidikan adalah melalui sekolah sedangkan lembaga nonformal adalah melalui lembaga kursus, pelatihan, dan lain sebagainya.

Salah satu mata pelajaran yang diajarkan di sekolah adalah pendidikan jasmani atau olah raga. Pendidikan jasmani merupakan mata pelajaran yang tidak dapat dipisahkan dari keseluruhan materi pembelajaran yang ada di sekolah. Pendidikan jasmani memberikan dampak positif bagi siswa, hal tersebut karena didalam pendidikan jasmani terdapat tiga hal yang diperhatikan yaitu aspek kognitif, afektif, dan psikomotorik.

$$
\text { Banyak cabang olahraga }
$$
yang dipelajari didalam pendidikan jasmani. Cabang olahraga tersebut secara garis besar dapat dibagi menjadi dua yaitu olahraga permainan dan bukan olahraga permainan. Olahraga permainan diantaranya adalah sepakbola, bulu tangkis, bolavoli, bolabasket, dan masih banyak lagi. Sedangkan olahraga bukan permainan diantaranya adalah atletik, senam, renang, catur, dan lain-lain.

Dalam pelaksanaan pembelajaran pendidikan jasmani sering didapati bahwa siswa lebih tertarik pada olahraga yang merupakan olahraga permainan dibandingkan olahraga yang bukan permainan. Walaupun tidak jarang sering juga siswa tidak tertarik pada keduanya dikarenakan guru belum menerapkan metode atau cara dalam memberikan materi pelajaran. Apabila siswa merasa kurang tertarik pada pembelajaran yang dilakukan guru maka yang terjadi adalah turunnya minat siswa dalam mengikuti pembelajaran. Siswa 
cenderung akan bertindak semaunya sendiri, bergurau dengan teman, tidak mengikuti pembelajaran dengan baik, atau bahkan yang lebih parah siswa membolos disaat pelajaran penjas dengan berbagai alasan. Sehingga hasil pembelajaran meroda rendah. Hal ini tidak boleh dibiarkan, guru harus dapat mengatasi permasalahan ini dengan cara memberikan model pembelajaran yang menarik minat dan peran aktif siswa. Dan perlu dipahami guru pendidikan jasmani, bahwa pendidikan jasmani mengutamakan pada berlangsungnya proses bukan pada hasil keterampilan sehingga keaktifan dan antusias siswa dalam mengikuti pembelajaran merupakan bukti dari kesuksesan pembelajaran.

Kesuksesan pembelajaran juga terlihat ketika siswa bersemangat dalam mengikuti pembelajaran olahraga. Guru perlu memahami kondisi siswa di lapangan dan tidak hanya menuntut pada ketercapaian Kriteria Ketuntasan Minimal (KKM) tetapi harus diimbangi dengan pembelajaran yang menarik sehingga pembelajaran tidak bersifat monoton dan lebih bervariasi. Sering kali siswa belum mengerti dan menguasai pembelajaran olahraga tertentu tetapi sudah dilakukan pengambilan nilai (evaluasi) sehingga akibatnya hasil belajar kurang optimal. Hasil belajar yang kurang optimal menyebabkan banyak siswa yang mengeluh karena merasa belum menguasai materi yang sudah diajarkan tetapi sudah diadakan penilaian. Keadaan demikian akan menyebabkan nilai yang diperoleh siswa menjadi tidak maksimal. Hal ini perlu dikoreksi meskipun guru dengan keterbatasan waktu yang dimiliki dapat mengefektifkan waktu dalam pembelajaran sehingga siswa mengerti dan memahami materi yang diajarkan.

Senam lantai atau senam ketangkasan merupakan salah satu sub mata pelajaran pendidikan jasmani yang diajarkan pada Sekolah Menengah Pertama. Gerakan senam lantai yang diajarkan di Sekolah Menengah Pertama antara lain adalah: meroda, guling depan dan guling belakang. Berdasarkan pengamatan saat pembelajaran 
senam lantai pada kelas VIII B SMP Negeri 1 Masaran diperoleh hasil bahwa masih banyak siswa yang belum maksimal dalam melakukan gerak meroda. Dari 32 siswa yang ada hanya 18 siswa $(56,25 \%)$ yang mampu melampui batas KKM, sementara 14 siswa $(43,75 \%)$ belum mampu melampaui batas KKM. Beberapa siswa melakukan gerak meroda tanpa memperhatikan teknik dasarnya. Hal itu berarti siswa belum mampu mengerti dan memahami bagaimana cara melakukan gerak meroda yang benar. Kesalahan umum yang terjadi adalah siswa tidak berani dalam melakukan gerakan meroda, karena takut untuk melakukannya ketika posisi tangan sebagai tumpuan dibawah dan kaki di bawa keatas. Sehingga banyak yang salah dalam hal tangan dan kaki (tidak lurus) maka siswa melakukannya dengan terpaksa dan asal melakukan gerakan meroda.

Hal tersebut dapat dipengaruhi oleh beberapa faktor, diantaranya adalah Proses Pembelajaran belum maksimal karena kurang tepatnya model pembelajaran penjas yang diterapkan sehingga partisipasi siswa rendah pada waktu pembelajaran berlangsung. Serta minimnya ketersediaan alat bantu untuk mempelajarinya bahkan tidak ada. Kegiatan pembelajaran yang diterapkan adalah guru memberikan penjelasan materi, memberikan contoh, kemudian menginstruksikan siswa untuk mencoba secara berulang-ulang.

Pembelajaran Penjasorkes dengan alat bantu pembelajaran merupakan salah satu karakteristik pembelajaran yang dapat diterapkan dalam pembelajaran penjas di sekolah. Adanya pembelajaran dengan penggunaan alat bantu dapat membantu seorang guru menciptakan suasana pembelajaran yang lebih baik sehingga motivasi siswa meningkat. Kemampuan seorang guru membangkitkan motivasi belajar siswa menjadi salah satu kunci tercapainya tujuan pembelajaran. Dalam proses belajar mengajar sarana dan alat bantu mengajar merupakan komponen yang tidak dapat dipisahkan dengan komponen-komponen lain, misalnya: 
tujuan, materi, metode dan sebagainya.

Pembelajaran pendidikan jasmani dengan alat bantu secara tidak langsung menuntut kreatifitas seorang guru penjas untuk menciptakan pembelajaran yang aktif, inovatif, kreatif, efektif dan memunculkan efek menyenangkan. Dengan syarat seorang guru penjas dapat mengorganisasi pembelajaran dan memotivasi anak untuk terlibat secara aktif dalam pembelajaran.

Penggunaan alat bantu pembelajaran merupakan salah satu solusi yang tepat untuk diterapkan guna mengatasi permasalahan pada pembelajaran gerak meroda senam lantai. Karena dengan menggunakan alat bantu pembelajaran membantu siswa di dalam melakukan gerak meroda senam lantai dengan benar sampai akhirnya nanti siswa mampu melakukan gerak meroda senam lantai dengan mandiri tanpa alat bantu lagi.

\section{KAJIAN PUSTAKA}

\section{Belajar Dan Pembelajaran}

Tidak dapat dipungkiri bahwa kehidupan manusia tidak

dapat terlepas dari satu hal yang dinamakan dengan belajar. Disadari atau tidak, melalui segala aktivitasnya manusia mendapatkan ilmu dan pengetahuan yang lebih banyak. Bertambahnya ilmu dan pengetahuan merupakan salah satu hasil dari belajar.

Suyono dan Hariyanto (2011:9) memberikan pengertian bahwa, "belajar adalah suatu aktivitas atau suatu proses untuk memperoleh pengetahuan, meningkatkan keterampilan, memperbaiki perilaku, sikap, dan mengokohkan kepribadian".

Menurut Hilgard (1962) yang dikutip Suyono dan Hariyanto (2011:12) dikatakan bahwa "belajar adalah suatu proses dimana suatu perilaku muncul atau berubah karena adanya respon terhadap suatu situasi".

Pengertian belajar menurut W.S. Winkel (1996) seperti dikutip Suyono dan Hariyanto (2011:14) menyatakan "belajar adalah suatu aktivitas mental atau psikis yang berlangsung dalam interaksi aktif dengan lingkungan yang menghasilkan perubahan-perubahan 
dalam pengetahuan, pemahaman, keterampilan, dan nilai sikap".

Aunurrahman (2014:35) menyatakan bahwa "belajar adalah suatu proses yang dilakukan individu untuk memperoleh suatu perubahan tingkah laku yang baru secara keseluruhan, sebagai hasil pengalaman individu itu sendiri didalam interaksi dengan lingkungannya".

Sedangkan menurut B.F. Skinner (1958) yang dikutip Syaiful Sagala (2010:14) "belajar adalah suatu proses adaptasi atau penyesuaian tingkah laku yang berlangsung secara progresif'.

Dari beberapa pengertian di atas, dapat disimpulkan bahwa belajar adalah suatu kegiatan kompleks yang dilakukan seseorang yang berdampak pada perubahan tingkah laku sebagai hasil dari proses belajar yang dilakukannya, baik melalui latihan maupun pengalaman yang menyangkut aspek kognitif, afektif, dan psikomotorik untuk memperoleh tujuan tertentu sehingga seseorang yang sebelumnya tidak tahu menjadi tahu.

\section{Senam}

Senam adalah istilah atau nama (nomen) suatu cabang olahraga. Sebagai cabang olahraga senam mempunyai domein atau daerah dengan batas-batasnya sendiri, mempunyai ruang lingkup yang tertentu. Ini berarti bahwa cabang olahraga senam berbeda dengan pencak silat, cabang olahraga senam tidak sama dengan sepak bola, dan bukan pula loncat indah.

Senam sebagai terjemahan dari istilah "gymnastic" mempunyai arti yang berbeda-beda sesuai dengan perkembangan zaman dan perkembangan pada umumnya. Senam mempunyai kaidah sendiri, tetapi seringkali kita mendengar seseorang sebelum melakukan berbagai cabang olahraga , melakukan pemanasan dahulu dengan gerakan senam. Seolah-olah latihan senam terdapat juga dalam cabang olahraga lain, sehingga senam mempunyai arti yang sempit dan arti yang luas. Gerakan lengan yang direntangkan dan tubuh yang dipilin ke kiri dan ke kanan sama dengan "senam pagi", tetapi senam pagi sebenarnya sebagian atau salah 
satu unsur dari arti kata senam yang sebenarnya. Senam pagi atau senam bebas adalah kata lain dari "calesthenic".

Untuk mengetahui definisi senam kita harus terlebih dahulu mengetahui batasan senam. Sementara untuk memberikan batasan yang tepat tentang senam sangat sukar, oleh karena semua pengertian dan bidang yang terkandung di dalamnya harus tercakup. Namun demikian batasan itu harus ada, supaya arti katanya tidak meragukan, tidak samar-samar dan agar supaya jelas batas dan ruang lingkupnya. Oleh karena harus kita coba memberikan batasan yang mendekati kebenaran.

\section{Senam Lantai}

Terdapat beberapa ahli yang memberikan definisi tentang senam dan jenis-jenis senam. Salah satu jenis senam adalah senam lantai. Berikut penulis akan kemukakan pengertian tentang senam lantai. Agus Margono

menyatakan bahwa:

Senam lantai adalah latihan senam yang dilakukan pada matras, unsur- unsur gerakannya terdiri dari mengguling, melompat, meloncat, berputar di udara, menumpu dengan tangan atau kaki untuk mempertahankan sikap seimbang atau pada saat meloncat ke depan atau ke belakang.

Pada dasarnya bentukbentuk latihan bagi putra dan putri adalah sama, hanya untuk putri banyak dimasukkan unsur-unsur balet. Didalam mempelajari atau berlatih senam seseorang tidak bisa langsung berlatih gerakan-gerakan yang mempunyai tingkat kesulitan tinggi.untuk itu belajar atau berlatih senam harus diawali dari dasar atau tingkat yang mudah, baru kemudian semakin meningkat ke arah gerakan yang sukar (tingkat kesulitan tinggi).

Dari pengertian senam lantai di atas dapat ditarik kesimpulan bahwa senam lantai adalah salah satu jenis dari senam. Sesuai dengan istilahnya maka gerakan senam lantai dilakukan di lantai atau matras. Dapat dikatakan juga bahwa senam lantai adalah senam yang gerakan-gerakannya dilakukan di lantai dengan latihan 
bebas dan tidak menggunakan alat atau benda.

\section{Meroda}

Meroda sering juga disebut baling-baling, Radslag, atau Cart Wheel adalah suatu gerakan ke samping dengan bertumpu atas kedua tangan dan kaki terbuka lebar. Meroda dapat dilakukan dengan gerakan ke kiri ataupun ke kanan.

Menurut Roji (2007:138) memberikan pengertian bahwa "meroda merupakan gerakan memutar badan dengan sikap awal menyamping arah gerakan dan tumpuan berat badan ketika berputar menggunakan kedua tangan dan kaki”.

Sedangkan Agus Mahendra (2000:56) menyatakan bahwa:

Keterampilan meroda atau baling-baling adalah gerakan yang menarik dan menyenangkan. Gerakannya cukup mudah dan relatif aman walaupun dilakukan dimana saja: di rumput, di lantai, atau di matras. Asal lengan dan bahu cukup kuat untuk menumpu badan maka keterampilan meroda akan mudah dikuasai.
Gerakan meroda dapat dilakukan dengan gerakan ke kiri maupun ke kanan. Perbedaan meroda kiri dan meroda kanan hanya berbeda dalam sikap awal dan urutan tangan serta kaki yang menyentuh lantai/matras. Untuk melakukan meroda ke kiri maka kaki yang diangkat pertama adalah kaki kiri, begitu juga dengan tangan yang pertama menyentuh lantai sebagai penopang adalah tangan kiri. Sedangkan untuk meroda ke kanan kaki yang diangkat pertama adalah kaki kanan dan tangan yang pertama menyentuh lantai adalah tangan kanan.

Dari pengertian meroda di atas dapat disimpulkan bahwa meroda merupakan salah satu gerakan senam lantai yang mengandalkan kekuatan tangan dan bahu sebagai penopang badan, gerakan meroda dapat dilakukan ke kiri maupun ke kanan.

\section{METODE}

Penelitian yang di gunakan adalah Penelitian Tindakan Kelas (PTK) subjek dalam penelitian ini adalah siswa kelas VIII B SMP 
Negeri 1 Masaran tahun pelajaran 2017/2018 yang berjumlah 32 siswa.

\section{HASIL DAN PEMBAHASAN}

Berdasarkan

hasil

pelaksanaan tindakan pada siklus I dan II dapat di lihat bahwa telah terjadi peningkatan hasil belajar gerak meroda senam lantai pada

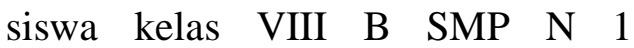
Masaran tahun pelajaran 2017/2018. Dari hasil yang diperoleh selama tindakan dilakukan, terjadi peningkatan yang signifikan pada kondisi awal ke siklus I dan dari siklus I ke siklus II. Pada kondisi awal nilai siswa pada kategori kurang dan kurang sekali sejumlah $43.75 \%$ dan pada kategori cukup dan baik sejumlah $56.25 \%$. Jumlah siswa yang mampu melampaui batas KKM atau masuk dalam kategori Tuntas sejumlah 18 siswa dan yang Belum Tuntas sejumlah 14 siswa.

Kemudian pada siklus I diterapkan pembelajaran gerak meroda dengan penggunaan alat bantu yang berupa gambar tangan kaki dan kardus. Penggunaan alat bantu pembelajaran bertujuan supaya siswa lebih tertarik terhadap kegiatan pembelajaran karena selama ini pembelajaran berlangsung monoton tanpa adanya variasi-variasi pembelajaran yang mampu meningkatkan minat siswa.

Hasil belajar gerak meroda pada Siklus I sudah menunjukkan adanya peningkatan dari kondisi awal. Persentase nilai siswa dengan kategori Baik adalah 3,125\%, Cukup $68,75 \%$ dan kategori Kurang 28,125 $\%$. Jumlah siswa yang mampu melampaui batas KKM atau masuk kriteria Tuntas adalah sejumlah 23 siswa dan yang masih dalam kriteria Belum Tuntas sejumlah 9 siswa.

Berdasarkan hasil refleksi dari Siklus I maka pada siklus II alat bantu yang digunakan juga ditambah dengan tali yang terbuat dari karet gelang.

Hasil belajar gerak meroda pada siklus II mengalami peningkatan dari siklus sebelumnya. Persentase hasil belajar siswa pada kategori Baik sejumlah 18,75 \%, Cukup 65,625\%, dan pada kategori Kurang sejumlah 15,625\%. Siswa yang mampu melampaui batas KKM sejumlah 27 siswa, sedangkan siswa yang masih belum mampu 
melampaui batas KKM sejumlah 5 siswa.

Penggunaan alat bantu pembelajaran pada siklus I dan II secara efektif membantu meningkatkan hasil belajar gerak meroda, walaupun masih terdapat siswa yang belum mampu melampaui batas KKM. Motivasi serta tingkat ketertarikan siswa dalam mengikuti pembelajaran juga meningkat. Penggunaan alat bantu pembelajaran menciptakan pembelajaran yang lebih aktif, efisien, efektif, dan menyenangkan.

\section{SIMPULAN DAN SARAN}

\section{Simpulan}

Berdasarkan penelitian yang telah dikemukakan di atas, maka dapat diketahui bahwa penggunaan alat bantu pembelajaran dapat meningkatkan hasil belajar gerak meroda senam lantai pada siswa kelas VIII B SMP N 1 Masaran tahun pelajaran 2017/2018. Dengan demikian, implikasi dari penelitian tindakan kelas ini adalah:

1. Penelitian tindakan kelas ini memberikan suatu gambaran yang jelas bahwa keberhasilan sebuah pembelajaran dipengaruhi oleh beberapa faktor. Faktor-faktor tersebut berasal dari pihak guru maupun siswa serta alat pembelajaran yang digunakan. Faktor dari pihak guru yaitu kemampuan guru dalam mengembangkan materi, kemampuan guru dalam menyampaikan materi, kemampuan guru dalam mengelola kelas, metode yang digunakan guru dalam proses pembelajaran, serta teknik yang digunakan guru sebagai sarana untuk menyampaikan materi. Sedangkan faktor dari siswa yaitu minat dan motivasi siswa dalam mengikuti proses pembelajaran. Selain itu, dengan adanya alat bantu pembelajaran akan menciptakan suasana yang kondusif dan siswa akan lebih terkontrol karena alat bantu yang tersedia cukup banyak sehingga siswa dapat menggunakannya.

2. Memberikan deskripsi yang jelas bahwa dengan penggunaan alat bantu pembelajaran dapat meningkatkan hasil belajar siswa (baik proses maupun hasil) karena 
melalui alat bantu pembelajaran memudahkan siswa dalam mempraktikkan gerak meroda sehingga penelitian ini dapat digunakan sebagai suatu pertimbangan bagi guru yang ingin menggunakan alat bantu pembelajaran.

3. Penggunaan alat bantu pembelajaran sebagai bentuk kreatifitas yang bertujuan untuk mengemas suatu pembelajaran yang menarik sehingga mempunyai hasil yang optimal pada proses pembelajaran. Alat bantu pembelajaran yang menarik akan menjadikan siswa terpacu untuk lebih aktif dalam proses pembelajaran. Dengan penggunaan alat bantu pembelajaran yang tepat, pembelajaran yang awalnya membosankan bagi siswa, menjadi pembelajaran yang menyenangkan bagi siswa.

Penggunaan alat bantu pembelajaran dalam pembelajaran ini dapat merangsang aspek keterampilan siswa. Dalam hal ini siswa dituntut untuk aktif dalam pembelajaran penjasorkes yang nantinya dapat bermanfaat untuk mengembangkan kebugaran jasmani, mengembangkan kerjasama, mengembangkan skill dan mengembangkan sikap kompetitif yang semuanya ini sangat penting dalam pendidikan jasmani

\section{Saran}

Sesuai dengan simpulan dan implikasi dari penelitian yang telah dilakukan, serta dalam rangka ikut menyumbangkan pemikiran bagi guru untuk meningkatkan kualitas pembelajaran bidang studi Penjasorkes, maka peneliti menyampaikan saran sebagai berikut:

1. Bagi Guru Penjasorkes SMP N 1 Masaran

a) Guru hendaknya lebih inovatif dalam menerapkan metode untuk menyampaikan materi pembelajaran dengan memaksimalkan penggunaan alat bantu pembelajaran.

b) Dalam proses pembelajaran harusnya guru memperhatikan kondisi siswa dan menggunakan strategi mengajar yang bervariasi. Dengan demikian 
motivasi dan keaktifan siswa akan meningkat pada mata pelajaran pendidikan jasmani.

c) Guru hendaknya lebih kreatif dalam membuat dan mengembangkan alat bantu pembelajaran sehingga akan menciptakan pembelajaran yang aktif dan menyenangkan.

d) Guru harus memberikan remidial untuk siswa yang belum lulus, dan pengayaan untuk siswa yang sudah lulus.

e) Guru hendaknya lebih membuka diri untuk menerima berbagai bentuk masukan, saran dan kritikan agar dapat lebih meningkatkan kualitas mengajarnya.
2. Bagi Siswa Kelas VIII B SMP N 1 Masaran

a) Siswa harus siap untuk mengikuti pembelajaran dengan strategi pembelajaran yang diberikan guru dan selalu bersedia dengan kesadaran sendiri untuk mengikuti petunjuk dan arahan yang diberikan guru.

b) Siswa perlu untuk lebih meningkatkan berbagai aktivitas, memperluas pengetahuan dan wawasannya, belajar secara mandiri, banyak berlatih diluar jam belajar untuk menggali dan meningkatkan kemampuan. 


\section{DAFTAR PUSTAKA}

Agus Kristiyanto. (2012). Penelitian Tindakan Kelas (PTK) Dalam Pendidikan Jasmani \& Kepelatihan Olahraga. Surakarta: UNS Press.

Agus Mahendra. (2000). Senam. Jakarta. Depdiknas.

Agus Margono. (2009). Senam. Surakarta : UNS Press.

Aunurrahman. (2014). Belajar dan Pembelajaran. Bandung: Alfabeta.

Azhar Arsyad. (2010). Media Pembelajaran. Jakarta: PT RAJAGRAFINDO PERSADA.

Basuki Wibawa \& Farida Mukti. (2001). Media Pengajaran. Bandung: CV. MAULANA.

Daryanto. (2013). Media Pembelajaran. Yogyakarta: Gava Media.

Ega Trisna Rahayu. (2013). Strategi Pembelajaran Pendidikan Jasmani. Bandung: Alfabeta.

Purwanto. (2014). Evaluasi Hasil Belajar. Yogyakarta: Pustaka Pelajar.

Sri Anitah. (2009). Media Pembelajaran. Surakarta: Panitia Sertifikasi Guru Rayon 13 FKIP UNS Surakarta.

Suyono \& Hariyanto. (2011). Belajar dan Pembelajaran. Bandung: Remaja Rosdakarya.

Syaiful Bahri Djamarah \& Azwan Zain. (2010). Strategi Belajar Mengajar. Jakarta: Rineka Cipta.

Syaiful Sagala. (2010). Konsep dan Makna Pembelajaran. Bandung: Alfabeta.

Wina Sanjaya. (2012). Perencanaan dan Desain Sistem Pembelajaran. Jakarta:

Kencana Prenada Media Group. 